РАХМАНОВ Никита Владимирович - аспирант кафедры теории и истории международных отношений Нижегородского государственного университета им. Н.И. Лобачевского (603950, Россия, г. Нижний Новгород, ул. Ульянова, 2; nikit.rahmanov@yandex.ru)

\title{
МЕЖДУНАРОДНЫЙ ТЕРРОРИЗМ НА СОВРЕМЕННОМ ЭТАПЕ, ЕГО РАЗВИТИЕ И ОСНОВНЫЕ ТЕНДЕНЦИИ
}

Аннотация. Современный мир переживает фундаментальные и динамичные изменения, связанные с процессом глобализации. С окончанием “холодной войны» происходит геополитическая реконструкция карты мира, распадаются старые и складываются новые внешнеполитические альянсы. В то же время процесс мировой глобализации стирает границы между внешней и внутренней политикой государств, между мировой и национальной культурой, приводит к общим вызовам, одним из которых является террористическая угроза.

Ключевые слова: международные отношения, глобализация, терроризм, террористические организации, Исламское государство, безопасность, противодействие терроризму

A нализ тенденций последних лет в системе международных отношений указывает на ее динамичное и фундаментальное изменение, появление в ней новых акторов. С течением времени все большее влияние на глобальные процессы оказывают такие субъекты, как транснациональные корпорации (ТНК), неправительственные международные организации (НMO), некоммерческие организации (НКО), а также частные военные компании (ЧВК).

По мере ускорения процесса глобализации, а также под воздействием биполярной конфронтации все более громко заявляет о себе культурно-цивилизационное многообразие современного мира [Пахомова 2014: 16]. Возрастает значение различных религиозных организаций в формировании системы современных международных отношений. Отметим также, что некоторые религиозные организации в современном мире как минимум косвенно причастны если не терроризму, то к его оправданию.

Понятия «терроризм», «террорист» появились во Франции в конце XVIII в. Так называли себя якобинцы, причем всегда с положительным оттенком. Однако во время Великой французской революции термин «террорист» превратился в синоним преступника. Вплоть до 70-х гг. XX в. деятельность террористов в основном носила материальный характер. На сегодняшний день это понятие приняло ярко выраженную исламистскую окраску и к настоящему времени имеет спектр различных оттенков и методов насилия.

Отметим, что отсутствие четкого разграничения мировым сообществом таких понятий, как терроризм, экстремизм, борьба за самоопределение и сепаратизм, приводит к росту числа террористических актов. Такому положению дел в т.ч. будет способствовать сложившаяся политика двойных стандартов некоторых государств (в первую очередь США и их партнеров), позволяющая реализовывать под предлогом борьбы с терроризмом свои политические, экономические и военные интересы в различных регионах мира.

Еще одной главной отличительной чертой современного терроризма является размывание границ между международным и региональным терроризмом. Террористическая угроза затронула практически все регионы мира и является одной из важнейших угроз национальной безопасности государств и мирового сообщества в целом. Это подтверждают и данные исследования, нашед- 
шие отражение в Глобальном рейтинге терроризма 2017 года ${ }^{1}$, составленном Британским институтом экономики и мира. Исследование основано на информации глобальной базы данных терроризма ${ }^{2}$ Национального консорциума по изучению терроризма при университете штата Мэриленд - крупнейшей в мире статистической базы террористической деятельности. Согласно данным исследования, в мире в период с 1970 по 2017 г. было зафиксировано более 180 тыс. терактов, в результате которых погибли, по разным оценкам, около 186 тыс. чел. Отметим, что более $40 \%$ террористических атак произошли за последние 6 лет. Анализ данных исследования показал, что наиболее уязвимыми регионами в отношении террористической угрозы являются Ближневосточный, СевероАфриканский и Южно-Азиатский регионы, на которые приходится около $60 \%$ всех террористических актов, причем половина из них приходится на такие государства, как Ирак, Афганистан, Нигерия, Сирия и Пакистан [Устинкин, Рогожина 2015: 217].

Современные террористические организации (ТО) имеют собственные источники финансирования (их доходы в совокупности сопоставимы с ВВП некоторых государств), а резко возросшая техническая оснащенность террористов позволяет практически беспрепятственно распространять свои радикальные идеи, оказывая влияние на морально-психологическое состояние граждан и устойчивость государственной власти. В совокупности указанные факторы дают возможность различным экстремистским группировкам делать свои атаки более точными, мощными и опираться на планомерную систематическую основу.

Появление и деятельность такой международной террористической организации, как запрещенное на территории Российской Федерации Исламское государство (ИГ, ИГИЛ), говорит нам о новом источнике угроз, исходящих от терроризма. Выступая на 70-й сессии Генеральной Ассамблеи ООН, президент РФ В.В. Путин заявил, что, «создав плацдарм в Сирии и Ираке, “Исламское государство” активно расширяет экспансию на другие регионы, нацеливается на господство в исламском мире, и не только там. Только этими планами явно не ограничивается. Положение дел более чем опасно» 3 .

Кульминационным событием в трансформации террористических организаций и эволюции терроризма как социально-политического явления в целом стало построение запрещенным в РФ Исламским государством четко выраженной структуры управления и вертикали власти. Наличие атрибутов власти, подобно легитимному государству, окончательно закрепило за ИГ статус квазигосударства, а экспансионистский подход руководства халифата ИГИЛ стало одной из приоритетных проблем мировой политики в связи с географическим характером угрозы. Боевики Исламского государства выступают крупнейшим дестабилизирующим фактором и без того беспокойного региона мира, затрагивая интересы как традиционных игроков на Ближнем Востоке, так и глобальных игроков. Кроме вызовов национальной и глобальной безопасности, ИГИЛ также является проводником других угроз, помимо терроризма: это контрабанда оружия и нефти, продвижение исламского фундаментализма, торговля людьми, древними реликвиями, наркотиками и т.д. [Косарев 2015: 21; Фитуни, Абрамова 2016: 5].

Одной из следующих проблем, с которой ведущие государства мира стол-

\footnotetext{
1 Global Terrorism Index, GTI. URL: http://www.globalterrorismindex.org (accessed 01.10.2018).

2 Global Terrorism Database, GTD. Доступ: http://www.start.umd.edu (проверено 01.10.2018).

3 Выступление президента РФ В.В. Путина на 70-й сессии Генеральной Ассамблеи ООН. 28.09.2015. - Официальный сайт Президента РФ. Доступ: http://kremlin.ru/events/president/news /50385 (проверено 01.10.2018).
} 
кнутся в будущем, - это укрепление террористических организаций в информационном пространстве, в частности в киберпространстве, для распространения своей идеологии и вербовки в экстремистские группировки [Старкин 2015: 37]. Наиболее успешно у эмиссаров ТО получается вербовать сторонников с помощью социальных сетей. Одной из первых групп, созданных в социальных сетях Фейсбук и ВКонтакте, был паблик «Новости Джихада в Сирии». И подобных сайтов с течением времени становится все больше. Если в 1998 г. их насчитывалось всего 12, а к 2005 г. - 4 800, то уже к 2013 г. - около 10 тыс. Из них на русском языке функционировали около 200. Зачастую объектом вербовки становятся психически неуравновешенные люди и граждане, которые испытывают материальные трудности, а также молодежь с радикальными антиправительственными взглядами.

В социальных сетях активно распространяются пропагандистские фото- и видеоматериалы, которые демонстрируют якобы счастливую и безбедную жизнь боевиков, их героизм, где осуществляется трансляция сцен их успехов в боевых действиях. Основная задача подобных продуктов - привлечь внимание объекта вербовки с целью его дальнейшей психологической обработки путем изоляции от близкого окружения и социума в целом и вовлечения в ряды террористов. Вербовщики ТО используют ту же самую технологию, что и тоталитарные секты.

Сегодня можно констатировать, что именно при помощи такой продукции в социальных сетях боевикам ИГИЛ удалось завербовать граждан практически из 100 стран мира. Выходцы из стран СНГ и Российской Федерации на 2016 г. составляли почти 1/6 иностранцев в террористической группировке - около 5 тыс. из 30 тыс. наемников. Одним из резонансных случаев такой вербовки стало дело студентки МГУ В. Карауловой, а также гибель актера В. Дорофеева за ценности и идеалы Исламского государства.

Последствия экспансии ИГ вызвали острейший миграционный кризис в ЕС. По данным Европейской комиссии, в период с 2015 по 2018 г. на территорию Европейского союза прибыли более 1,65 млн нелегальных мигрантов 1 [Устинкин, Морозова, Куконков 2018: 456]. Этому способствовала кризисная ситуация в регионах Ближнего Востока и Северной Африки. Под видом беженцев в страны Европы проникают также члены экстремистских группировок, в частности ИГИЛ, для формирования так называемых скрытых ячеек с целью активизации террористической деятельности. Наметилась тенденция совершения терактов в традиционных местах отдыха европейцев (серия атак в Париже, атака на рождественскую ярмарку в Берлине, взрыв на концерте в Манчестере и т.д.) - все это делается с целью максимального воздействия на моральное и психологическое состояние граждан, формирование состояния перманентной напряженности и незащищенности населения перед террористической угрозой [Зеленков 2017: 90].

Следует отметить, что боевики в основном действуют в тех европейских государствах, которые формировали политическую и военную обстановку в отмеченных выше регионах, а также в странах, которые включились в антитеррористическую операцию в Сирии и Ираке.

Такое положение дел заставляет мировое сообщество реагировать на ситуацию и делать шаги к сотрудничеству против глобальной террористической угрозы. Это сотрудничество нашло свое отражение как на глобальном, так и на региональном уровнях. Оно выразилось в следующих действиях:

\footnotetext{
1 Миграционный кризис в Европе: Досье. - Сайт РИА «ТАСЪ. 29.06.2018. Доступ: http://www.tass. ru (проверено 01.10.2018).
} 
- принятии Конвенции Совета Европы 2005 г. по борьбе с терроризмом;

- выработке Глобальной стратегии ООН по борьбе с терроризмом;

- создании специальной комиссии по борьбе с терроризмом, которая оказывает содействие государствам-членам в реализации Глобальной стратегии ООН по борьбе с терроризмом;

- учреждении 15 июня 2017 г. Контртеррористического управления ООН.

Кроме того, собираются международные конгрессы по данному вопросу, страны заключают договоры о сотрудничестве в вопросах защиты от террористических атак.

Однако следует принимать во внимание, что запрещенное в РФ ИГИЛ вышло за рамки исключительно террористической угрозы. Подобно инструменту социальной инженерии, фактор Исламского государства необходим правящим элементам Запада в качестве консолидации последнего и глобального управления. Вместе с тем феномен «халифата» активно используется политическими игроками для «разжижения» гражданского общества, основанного на национальном компоненте, в странах, исторически сложившихся как государстванации. В этом контексте следует понимать, что даже в случае исчезновения угрозы, исходящей от ИГ, в перспективе нельзя исключить появление на его месте другой управляемой террористической организации подобного рода.

Из сказанного выше можно сформулировать эволюцию субъектов террористической деятельности. Рассматривая развитие запрещенного в РФ Исламского государства, экстраполируем возможность появления в будущем еще одного субъекта - управляемого террористического государства, которое де-юре будет официально признано хотя бы некоторыми действующими субъектами международных отношений и в основе своего существования поставит цель, которая может быть достигнута с помощью террористических методов и под религиозными лозунгами. Только всемерная и всемирная борьба с террористическими организациями может сделать появление такого актора международных отношений невозможным.

\section{Список литературы}

Зеленков М.Ю. 2017. Современный терроризм - угроза общественной безопасности Российской Федерации. - Противодействие экстремизму и терроризму: материалы международной научно-практической конференции. М.: Московская академия Следственного комитета РФ. С. 88-93.

Косарев М.Н. 2015. Тенденции современного терроризма: Исламское государство» как новая угроза безопасности. - Вестник Уральского юридического института МВД России. № 3. С. 20-22.

Пахомова Е.А. 2014. Либералы против большинства: На примере отношения к «пятидневной войне». - Научное мнение. № 10-3. С. 14-20.

Старкин С.В. 2015. Кибербезопасность и киберреволюция: Критический анализ базовых концептов. - Вестник Московского университета. Сер. 12. Политические науки. № 1. С. 35-53.

Устинкин С.В., Морозова Н.М., Куконков П.И. 2018. Миграционные потоки и баланс социальных отношений в принимающем обществе. - Россия реформирующаяся: ежегодник. Вып. 16 (отв. ред. М.К. Горшков). С. 455-471.

Устинкин С.В., Рогожина Е.М. 2015. Международный круглый стол «Образование-путьвбудущее, терроризм-вникуда!»-Вестник Нижегородского государственного лингвистического университета им. Н.А. Добролюбова. № 32. С. 216-219.

Фитуни Л.Л., Абрамова И.О. 2016. Резервная армия ИГИЛ: Ресурс и маневр. - Азия и Африка сегодня. № 12(713). С. 2-8. 
RAKHMANOV Nikita Vladimirovich, postgraduate student at the Chair of Theory and History of International Relations, Lobachevsky State University of Nizhny Novgorod (2 Ul'yanova St, Nizhny Novgorod, Russia, 603950; nikit.rahmanov@ yandex.ru)

\section{INTERNATIONAL TERRORISM AT THE PRESENT STAGE, ITS DEVELOPMENT AND THE MAIN TRENDS}

Abstract. The modern world is experiencing fundamental and dynamic changes associated with the process of globalization. For the first time since the end of the cold war, the geopolitical reconstruction of the world map is taking place, old and new foreign policy alliances are breaking up. At the same time, the process of globalization blurs the boundaries between the foreign and domestic policies of states, between the world and national culture, leads to common challenges, one of which is the terrorist threat.

Keywords: international relations, globalization, terrorism, terrorist organizations, ISIL, security, counter-terrorism 